\title{
Occurrence of the Common Amber Snail Succinea Putris (L.) (Gastropoda: Styllomatophora) on Japanese Knotweed (Fallopia Japonica [Houtt.] Ronse Decraene) in Slovenia - Possible Weed Biocontrol Agent?
}

\author{
Žiga Laznik ${ }^{1} \&$ Stanislav $\operatorname{Trdan}^{1}$ \\ ${ }^{1}$ Department of Agronomy, Biotechnical Faculty, University of Ljubljana, Jamnikarjeva 101, SI-1000 Ljubljana, \\ Slovenia \\ Correspondence: Žiga Laznik, Department of Agronomy, Biotechnical Faculty, University of Ljubljana, \\ Jamnikarjeva 101, SI-1000 Ljubljana, Slovenia. E-mail: ziga.laznik@bf.uni-lj.si
}

Received: September 19, 2016 Accepted: October 20, 2016 Online Published: January 28, 2017

doi:10.5539/sar.v6n2p21 URL: http://dx.doi.org/10.5539/sar.v6n2p21

\begin{abstract}
Japanese knotweed, Fallopia japonica is one of the most troublesome invasive alien plant in Europe and North America. In 2012 we started monitoring for possible indigenous natural enemies of Japanese knotweed in Slovenia. In Zgornji Log, near Litija $\left(46^{\circ} 4^{\prime} 38.09^{\prime \prime} \mathrm{N}, 14^{\circ} 49^{\prime} 31.65^{\prime \prime} \mathrm{E} ; 245 \mathrm{~m}\right)$ on the river Sava, we recorded several plants of $F$. japonica damaged by the common amber snail Succinea putris. In this paper we discuss the possibility of the biological control of Japanese knotweed with S. putris.
\end{abstract}

Keywords: Fallopia japonica, Succinea putris, Slovenia, biological control

\section{Introduction}

Japanese knotweed, Fallopia japonica (Houtt.) Ronse Decraene var. japonica (Polygonaceae) is a perennial herb, native to Asia including China, Japan and Korea. Japanese knotweed was introduced into Europe in the first half of the nineteenth century (Bailey, 1994) and into US (Patterson, 1976) as an ornamental plant, and has become one of the most troublesome invasive alien plant in Europe and North America in recent years (Gerber et al., 2008). It can propagate by both sexual reproduction and clonal growth from rhizomes and stem fragments (Wang et al., 2007). The species thrives in riparian ecosystems, where water is readily available, but it can also be found in relatively dry areas. Once a ramet has established, it can spread clonally by rhizomes, forming dense stands, and reducing the available habitat for other organisms (Gerber et al., 2008). The rapid spread of this invasive plant in its adventive range is likely to be a result of decreased regulation by specialist herbivorous natural enemies. In addition to a lack of co-evolved specialist natural enemies, increased growth and invasion of non-native weed could be the result of growth adaptations (phenotypic plasticity) or selection for fast-growing genotypes in the invasive range (evolution of increased competitive ability) (Keane \& Crawley, 2002).

Strgar (1982) reported a massive expansion of Japanese knotweed in Slovenia expecially near the rivers of Drava, Meža, Sotla, Savinja and Sava. Most recently the research of Jogan (2006) reported of a major range expansion of $F$. japonica to all parts of the country (except the submediteranean), as a result of disturbance, such as flood events which move rhizome fragments along river systems, and human activity, in particular the illegal dumping of waste and top soil contaminated with rhizome fragments. Control is extremly difficult since the plant has an extensive rhizome system which survives despite mechanical and chemical control (Laznik \& Trdan, 2012).

Considering the scale of classical biocontrol efforts around the globe (Cowie, 2001) and the world-leading biological pest management strategies implemented in European covered crops (Eilenberg et al., 2000), it is surprising how little effort has been targeted at exotic weeds in Europe. Until recently (Shaw et al., 2009) no full classical weed-biocontrol programme has been carried out in any European Union Member State (Shaw et al., 2003). For a diverse array of other reasons (e.i. strict plant protection regulations in several other countries, including Slovenia) the use of a exotic biological control agent will still be prohibited. Therefore the aim of our current research was to search for an indigenous biocontrol agent of $F$. japonica, which could be systematically used for controlling this increasingly harmful invasive plant in Slovenia. 
The taxonomy and ecology of different species of Succineidae has been mostly studied in the United States (Patterson, 1971; Hubricht, 1985). Data on ecology and life history of the Succineidae in Europe are scarce (Cejka, 1999). Rigby (1965) reported some data on the histology, functional morphology and some aspects of life history of Succinea putris (Linnaeus 1758). Nine species of the family Succineidae are found in Europe and four in Slovenia. These are S. putris, S. oblonga (Draparnaud 1801), Oxyloma elegans elegans (Risso 1826) and Oxyloma elegans (Risso 1826) (Slapnik, 2005; Fauna Europaea, 2013).

S. putris is one of the most abundant Succineidae species in Slovenia. Despite its wide distribution and importance as an intermediate host of Leucochloridium spp., there are no published studies on its biology in Slovenia (Velkovrh, 2003). Several other authors (Hubricht, 1985; Đatkauskienë, 2005) report that the common amber snail lives on reed and other plants standing near the water, on constantly humid meadows, in alluvial forests and in forests on swampy ground. The snail often crawls up plant stems and can hibernate at some distance from water (Cejka, 1999).

\section{Material and Methods}

In 2012 we started monitoring for possible indigenous natural enemies of Japanese knotweed in Slovenia. We surveyed 38 places in Slovenia, mainly alongside rivers Sava, Savinja and Drava. In each place we collected 5 plants of Japanese knotweed. In Zgornji Log, near Litija $\left(46^{\circ} 4^{\prime} 38.09^{\prime \prime} \mathrm{N}, 14^{\circ} 49^{\prime} 31.65^{\prime \prime} \mathrm{E} ; 245 \mathrm{~m}\right)$ on the river Sava, we recorded several plants of $F$. japonica damaged by snails (Figure 1). Snails (20) were collected and dissected and determination of the species was made analysing the reproductive system of the snails.

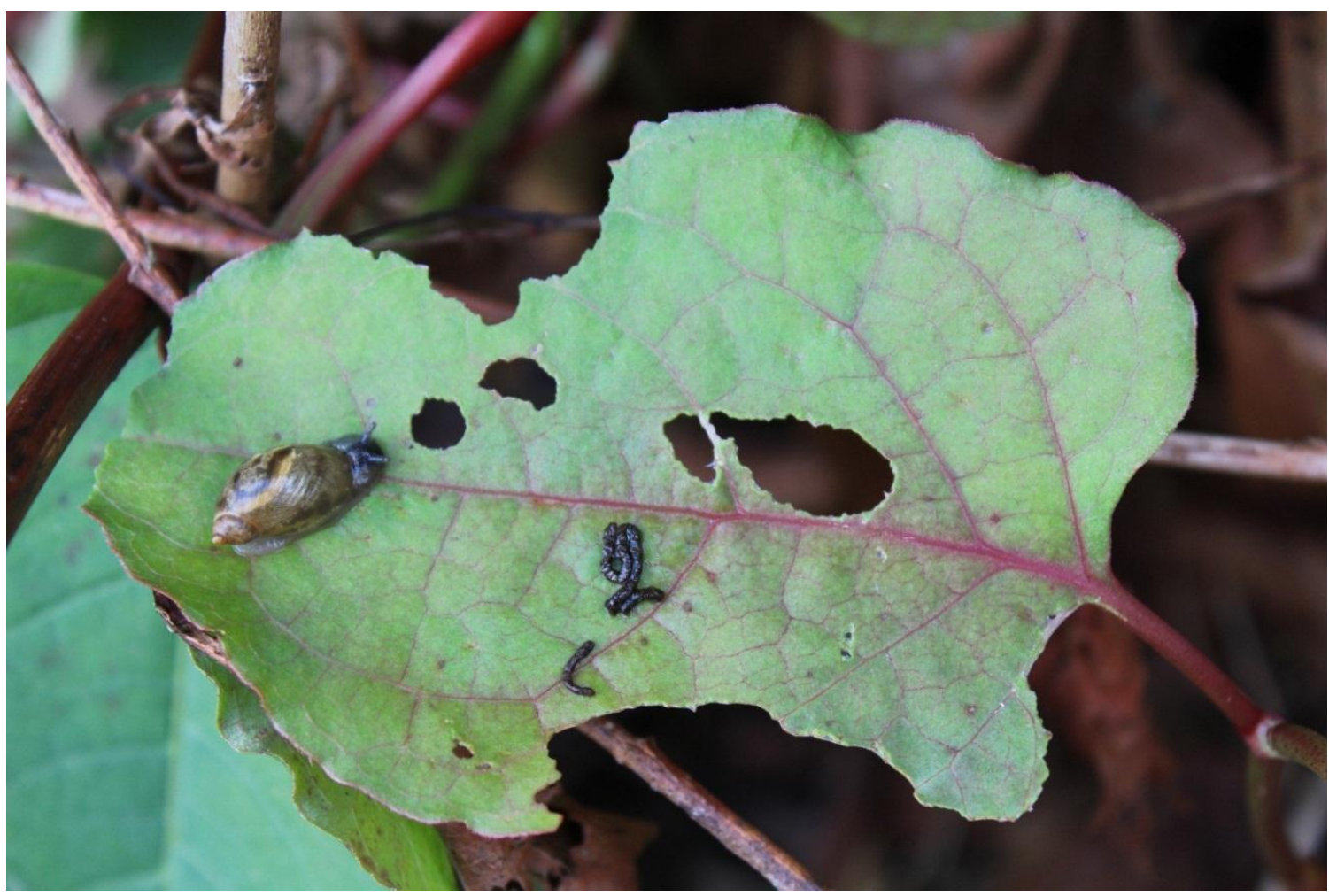

Figure 1. The common amber snail S. putris feeding on the plant of Japanese knotweed (F. japonica) near river Sava (Slovenia)

\section{Results and Discussion}

Analysis confirmed the presence of the common amber snail S. putris. Results of our observation showed that $S$. putris was feeding only on Japanese knotweed, on other related species such as F. convolvulus (L.) Löve, $F$. dumetorum (L.) Holub, F. baldschuanica (Regel) Holub, F. sachalinensis (F. Schmidt) Ronse Decraene, F. x convolvuloides (Brügger) (Holub) and $F$. x bohemica (Chrtek \& Chrtkova) J. P. Bailey was not present.

The goal of weed biological control is not to eradicate the weed but rather to reduce its vigor so that desirable plants can coexist (van Driesche et al., 2008). Compared with the extensive use of insects for biological control, snails have been used in relatively few biocontrol efforts (Cowie, 2001). Most snail species, both herbivorous 
and predatory species, are generalists. This fact, combined with the fact that most biocontrol introductions using snails have been and continue to be undertaken by people with entomological, but not malacological, experience, as noted for example by Mead (1955) and van der Schalie (1969), has meant that adequate understanding of snail biology has not been incorporated into the biocontrol efforts. Many classical biocontrol introductions had major impacts on non-target organisms, in some cases leading to the extinction of native species, and others have the clear potential for such impacts (Cowie, 2001). Any putative biocontrol agents used to control plants would have to be shown, prior to release, to be specific to the target weed it is intended to control, as well as demonstrating capable to reduce populations of that weed (Cowie, 2001). It is unlikely that many gastropod will be found that can filfill these criteria. An extensive review of attempts to control pest molluscs using predatory gastropods can be found in Barker \& Efford (2004).

Nearly all efforts at weed biological control have involved classical biological control based on the introduction of insects or plant pathogens from the host plant's native range (van Driesche et al., 2008). In a few cases, generalists fish, such as the grass carp, have been used to graze down the biomass of macrophytic water plants in a non-specific way. In the review of Cowie (2001) the author presents data on several attempts to control aquatic weeds with snails (Robins, 1971; Thomas, 1975; Horne et al., 1992; Okuma et al., 1994; Perera \& Walls, 1996). Some of the biocontrol efforts mentioned above probably can be considered successful from the perspective of controlling the target organisms. For many, however, success has not been demonstrated.

A survey by Shaw et al. (2009) revealed that 186 species of phytophagous arthropods are associated with $F$. japonica in its native range. Four years of research, funded by a consortium of UK and North American sponsors, demonstrated that a psyllid species, Aphalara itadori Shinji, had the highest potential as a classical biocontrol agent (Shaw et al., 2011).

Here the snail $S$. putris is in suggested, for the first time, as a possible native biocontrol agent which we recommend should be tested for its ability to regulate $F$. japonica. As a native species none of the dangers inherent to classical introductions are relevant. In a related research, Podroužková (2011) investigated food preferences of two snail species, Succinea putris and Urticicola umbrosus C. Pfeiffer, among five widespread invasive plant species from river floodplains: Impatiens glandulifera Royle, Helianthus tuberosus L., F. japonica, F. sachalinensis F. Schmidt and F. x bohemica (J. Chrtek \& A. Chrtkova) J.P. Bailey and one native species, Urtica dioica L. Laboratory experiments showed that the most important factors affecting snails food preferences were plant species and the condition of plant material. U. umbrosus consumed much less fresh material than S. putris. In their research Fallopia spp. were rejected, whether fresh or previously frozen, which does not correspond with our field observations, where several plants of $F$. japonica were severe damaged by $S$. putris. In future we would like to test $S$. putris to determine their food preference to different Fallopia species in Slovenia and possible impacts on non-target plants.

\section{Acknowledgements}

This study was carried out within Professional Tasks from the Field of Plant Protection, a programme funded by the Ministry of Agriculture and Environemnt - Phytosanitary Administration of the Republic of Slovenia.

\section{References}

Bailey, J. P. (1994). Reproductive biology and fertility of Fallopia japonica (Japanese knotweed) and its hybrids in the British Isles. Pages 141-158. In: de Waal, LC, LE Child, PM Wade, \& JH Brock (eds.): Ecology and Management of Invasive Riverside Plants. New York: J. Wiley.

Barker, M. B., \& Efford, M. G. (2004). Predatory gastropods as natural enemies of terrestrial gastropods and other invertebrates. In Barker GM (ed.), Natural Enemies of Terrestrial Molluscs, pp. 279-403. CABI Publishing, Wallingford, UK. https://doi.org/10.1079/9780851993195.0279

Cejka, T. (1999). The terrestrial molluscan fauna of the Danubian floodplain (Slovakia). Biologia, 54, 489-500.

Cowie, R. H. (2001). Can snails ever be effective and safe biocontrol agents? International Journal of Pest Management, 41, 23-40. https://doi.org/10.1080/09670870150215577

Đatkauskienë, I. (2005). Characteristic of lifespan and reproduction period of Succinea putris (L.) (Gastropoda: Styllomatophora). Ekologija, 3, 28-33.

Eilenberg, J., Enkegaard, A., Vestergaard, S., \& Jensen, B. (2000). Biocontrol of pests on plant crops in Denmark: present and future potential. International symposium on biological control agents in crop and animal protection, Swansea, UK, 24-28 August, 1999. Biocontrol Science and Technology, 10, 703-710.

https://doi.org/10.1080/09583150020011681 
Fauna Europaea. (2013). www.faunaeur.org. 24(8). 2013

Gerber, E., Krebs, C., Murrell, C., Moretti, M., Rocklin, R., \& Schaffner, U. (2008). Exotic invasive knotweeds (Fallopia spp.) negatively affect native plant and invertebrate assemblages in European riparian habitats. Biological Conservation, 141, 646-654. https://doi.org/10.1016/j.biocon.2007.12.009

Horne, F. R., Arsuffi, T. L., \& Neck, R. W. (1992). Recent introduction and potential botanical impact of the giant rams-horn snail, Marisa cornuarietis (Pilidae), in the Comal Springs ecosystem of central Texas. Southwestern Naturalist, 37, 194-196. https://doi.org/10.2307/3671668

Hubricht, L. (1985). The distribution of the native land mollusks of the eastern United States. Zoology, 24, 191.

Jogan, N. (2006). Japonski dresnik (Fallopia japonica) rastlina leta 2006. Proteus, 68, 437-440. [Slovenian]

Jordaens, K., Pinceel, J., \& Backeljau, T. (2005). Mate choice in the hermaphroditic land snail Succinea putris (Stylommatophora: Succineidae). Animal Behaviour, 70, 329-337. https://doi.org/10.1016/j.anbehav.2004.10.021

Keane, R. M., \& Crawley, M. J. (2002). Exotic plant invasions and the enemy release hypothesis. Trends in Ecology and Evolution, 17, 164-170. https://doi.org/10.1016/S0169-5347(02)02499-0

Laznik, Ž., \& Trdan, S. (2012). Damage potential of Japanese knotweed (Fallopia japonica) and its biological control with psyllid Aphalara itadori Shinji. Acta Agriculturae Slovenica, 99, 93-98. [Slovenian]

Mead, A.R. 1955. The proposed introduction of predatory snails into California. The Nautilus, 69, 37-40.

Okuma, M., Tanaka, K., \& Sudo, S. (1994). Weed control method using apple snail (Pomacea canaliculata) in paddy fields. Weed Research, 39, 114-119. https://doi.org/10.3719/weed.39.114

Patterson, C. M. (1971). Taxonomic studies of the land snail family Succineidae. Malacological Review, 4, 131-202.

Patterson, D. T. (1976). The history and distribution of five exotic weeds in North Carolina. Castanea, 41, 177-180.

Pemberton, C. E. (1956). Defense of a predator. The Nautilus, 69, 142-144.

Perera, G., \& Walls, J. G. (1996). Apple snails in the aquarium (Neptune City, New Jersey: TFH Publications, Inc.), $121 \mathrm{pp}$.

Podroužková, Š. (2011). Food preferences of land snails in a river flood-plain invoved with invasive plants. Diploma thesis.

Rigby, J. E. (1965). Succinea putris: a terrestrial opisthobranck mollusk. Proceedings of the Zoological Society of London, 144, 445-486. https://doi.org/10.1111/j.1469-7998.1965.tb05194.x

Robins, C. H. (1971). Ecology of the introduced snail, Marisa cornuarietis (Ampullariidae) in Dade County, Florida. The Biologist, 53, 136-152.

Shaw, R. H. (2003). Biological control of invasive weeds in the UK: opportunities and challenges. In: Child, L., Brock, J.H., Brundu, G. (Eds.), $6^{\text {th }}$ International conference on the cology and management of alien plant invasions (EMAPi), 12 to 15 September 2001, Loughborough, UK. Plant Invasions: Ecological threats and management solutions, 337-354.

Shaw, R. H., Bryner, S., \& Tanner, R. (2009). The life history and host range of the Japanese knotweed psyllid, Aphalara itadori Shinji: Potentially the first classical biological weed control agent for the European Union. Biological control, 49, 105-113. https://doi.org/10.1016/j.biocontrol.2009.01.016

Shaw, R. H., Tanner, R., Djeddour, D., \& Cortat, G. (2011). Classical biological control of Fallopia japonica in the United Kingdom - lessons for Europe. Weed Research, 51, 552-558. https://doi.org/10.1111/j.1365-3180.2011.00880.x

Slapnik, R. (2005). Mollusks in park Škocjanske jame. Annal Ser Hist Nat, 15, 265-276. [Slovenian]

Strgar, V. (1982). Genus Reynoutria v adventivni flori Slovenije, II. Biološki vestnik, 30, 151-154. [Slovenian]

Thomas, K. J. (1975). Biological control of Salvinia by the snail Pila globosa Swainson. Biological Journal of the Linnean Society, 7, 243-247. https://doi.org/10.1111/j.1095-8312.1975.tb00227.x

Van der Schalie, H. (1969). Man meddles with nature - Hawaiian style. The Biologist 51: 136-146.

Van Driesche, R., Hoddle, M., \& Center, T. (2008). Control of pests and weeds by natural enemies. An 
introduction to biological control. Blackwell publishing, $473 \mathrm{pp}$.

Velkovrh, F. (2003). Mollusks- Mollusca. In: Sket, B., Gogala, M., Kuštor, V. (Eds.). Animals of Slovenia. 109-132 [Slovenian].

Wang, Q., Wang, S., \& Zhang, S. (2007). The artificial multiplication method of Fallopia japonica. Journal of Chinese Medicinal Materials, 30, 1209-1210.

\section{Copyrights}

Copyright for this article is retained by the author(s), with first publication rights granted to the journal.

This is an open-access article distributed under the terms and conditions of the Creative Commons Attribution license (http://creativecommons.org/licenses/by/3.0/). 